\title{
The optimizing strategy of the library as a learning source center using AHP and Delphi methods
}

\author{
Adi Bandono *, Avando Bastari and Okol Sri Suharyo \\ Indonesian Naval Technology College, STTAL Surabaya Indonesia.
}

Global Journal of Engineering and Technology Advances, 2021, 07(03), 062-070

Publication history: Received on 02 May 2021; revised on 07 June 2021; accepted on 09 June 2021

Article DOI: https://doi.org/10.30574/gjeta.2021.7.3.0079

\begin{abstract}
Various efforts have been made by teachers or educator managers to further improve and support a more effective and efficient learning process. Although many factors determine the quality of education or learning outcomes, one of them is related to the learning resource center. The problem in this research is how to increase the role of the school library as a learning resource center. The purpose of this research is to make a strategic plan for the development of the school library in achieving educational goals, namely the results of students who excel. The method used in this research is the determination of the criteria weight based on the hierarchy using Analytical Hierarchy Process (AHP) and the determination of some criteria using the Delphi technique. The results showed that strategic priority using the AHP concept obtained 5 strategies, namely 1) Common learning services with the highest weight, 0.42. 2) Multitasking service with a weight of 0.23 . 3) Maker space service with a weight of 0.18. 4) Digital collection services with a weight of 0.11 , and 5) Audio-visual services with a weight of 0.06 .
\end{abstract}

Keywords: Strategy; AHP; Library Optimization; Learning Resources

\section{Introduction}

In the current era of the education system, students are encouraged and trained to develop scientific skills such as searching, collecting, observing, experimenting, and concluding existing data. With the help of learning media and learning resources that have been prepared by the school institution, it is very influential on the development of these students thinking skills (Monica, et al., 2018).

Various efforts have been made by teachers or educator managers to further enhance and support a more effective and efficient learning process. Although many factors determine the quality of education or learning outcomes, one of them is related to the learning resource center. Many various sources can be used as a learning resource center, one of which is the library. Libraries need to be preserved and well managed because they play a very important role in encouraging the effectiveness and optimization of the learning process through the implementation of various functions including service functions, learning media procurement/development functions, research and development functions, and other relevant functions to increase the effectiveness and efficiency of learning (Bandono, et al., 2019).

Along with the development of world technology, the development of a manual library computer system also follows the latest developments, it is necessary to develop it into an automation-based system. Where this system will later make it easier for users, especially library managers, to be more flexible in the system of borrowing, returning, and collecting books automatically. System Automation is also related to and associated with internet-based library computer systems or what is often called Modern Libraries. The definition of a library automation system here is to use computers and other technological means in an integrated manner for various routine activities in the library

\footnotetext{
${ }^{*}$ Corresponding author: Adi Bandono

Indonesian Naval Technology College, STTAL Surabaya Indonesia.
} 
(procurement, processing, tracking services, and circulation transactions) to improve the quality of library services (Liu, 2010).

Various problems surround the current library so it can be said that it is difficult to develop, namely, the Librarian is the spearhead for the success of a library in increasing students' reading interest. However, this profession has not received the proper attention from related parties and many do not even know the role of the librarian function. Some sources state that every time there is a recruitment of employees, it is rare for local governments in Indonesia to submit formations for librarian functional positions for graduate or library diplomas. Meanwhile, currently, the number of librarians in Indonesia is still very small (Sandanayake, 2019).

Another fundamental thing about libraries so far is the lack of procurement of new library materials every year. Even though the procurement of new library materials is very, very useful to provide a refreshing effect on the collection of existing library materials, as well as to replace outdated library materials.

Students' low reading interest should not be used as a justification or reinforcing reason for the decline in the world of libraries in general. The presence of the library is expected to be able to increase students' reading interest. So that if our students' interest in reading does not increase, then it is certainly an indicator of a wrong policy towards libraries in the school environment.

The library aims to provide services to readers, increase reading fondness, and broaden insight and knowledge to educate the nation's life and get a complete Indonesian human being.

From the description above, there is a common thread that can be concluded that the library is a place to transform information through the collection of library materials it already has. The existence and presence of a library are to empower the community, especially students to have awareness of the importance of good information. Awareness of the importance of information is what is commonly referred to as the information literacy process. So that it takes maximum effort in empowering the library so that it can function as its basis and as a source of learning in schools.

Based on a study on previous research on libraries as a learning resource in schools, it is stated that the ideal library is a library that can empower students. Included in it is a library that can and can make significant changes to the reading interest of students. Able to change the direction of view and also the character of students from disliking even unwilling to read to being fond of reading. Making students with information disabilities become learners who are literate or understand information.

The more varied the kinds of collections a library has, the more it will attract readers. Likewise, a complete library menu will have a great opportunity in presenting users from students. Galileo Galilei once said that you can not teach someone something, but you can only help that person find something in him. The library exists to break the shackles that shackle students' reading interest. The shackles of students' interest in reading are at least caused by three things, namely First, the shackles of genetics/heredity. This means that those who are raised in a family environment that does not like reading tend to give birth to children who also do not like reading, a child will tend to imitate the habits of their parents.

Second, the shackles of education/school. The educational orientation in schools that currently prioritizes passing each final exam has either directly or indirectly killed students' interest in reading. This means that for students, to achieve graduation in the several subjects tested, students take a more practical way, namely by following the model study guidance. This is not wrong, but this kind of learning model can include the creativity and innovation of students that can only be obtained through the reading process.

Furthermore, the third, namely social shackles. Association has a considerable influence in shaping a person's character. Friends at school and at home who don't like to read will result in someone not like reading too. Those who live in an environment that likes to read also like to read too.

This paper has many literatures to support the research, such as literature with title The use of value clarification technique-based- picture story media as an alternative media to value education in primary school (Fariyatul \& Bandono, 2017), STTAL Development Strategy To Produce Human Resources That Acknowledge Technology Facing The Industrial Revolution Era 4.0 (Mashudi, Rahman, Bandono, \& Hasan, 2019), Three different design approaches (Alammary, Sheard, \& Carbone, 2014), The effectiveness of wikis for project-based learning in different disciplines in higher education (Chu \& Zhang, 2017), Use interactive Sessions and E-learning in Teaching Anatomy to First-year Optometry Student (Chodhury, Gouldsborough, \& Gabriel, 2010), Optional Anatomy and physiology E-learning 
resources: student access, learning approaches and academic outcomes (Guy, Byrne, \& Dobos, 2018), Web 2.0 technologies for learning: the current landscape-opportunities, challenge and tensions (Crook, Fisher, \& Harrison, 2008), Student perceptions of various E-leearning components (More, 2008), Barriers to adult learning: Bridging the gap (Marina, 2011).

The research was organized as follows, part 1 was the introduction, part 2 presented the literature review and methodology, section 3 presented the results and data analysis, and part 4 presented the conclusions.

\section{Material and methods}

\subsection{Learning Resources}

Learning resources are all available sources in the form of data, humans, and certain forms that can be used by students in learning, whether used separately or as a whole so that it can make it easier for students to achieve learning goals or achieve certain desired competencies (Ahmed \& Khanam, 2014).

The function of learning resources is to increase learning productivity through accelerating the pace of learning and helping teachers to use time better and efficiently and to reduce the burden on teachers in presenting information so that they can foster and develop more interest in learning. Provides the possibility of learning that is more individual in nature, Provides a more scientific basis for learning, More solidifying learning, Allows instantaneous learning, Allows the presentation of broader learning, by presenting information that can penetrate geographic boundaries (Busljeta, 2013).

\subsection{Strategic Management Theory}

Good strategic management can lead an organization to implement its strategy through program planning, budgeting processes, performance management systems, changes in organizational structure, and program and project management (Rastislav \& Silvia, 2015). Also, strategic management theory can be linked to a strategic plan that is carried out to plan a strategy in making decisions to realize the desired goal (Bento \& White, 2014).

Another definition of strategic management is a series of fundamental decisions and actions made by top management and implemented by all levels of an organization to achieve the organization's goals.

\subsection{Delphi Analysis Concept}

The Delphi method is a method that is run through the creation of a series of questionnaires which are given to the experts to reach a consensus of their opinion. The Delphi method was developed in the early 1950s by Derkley and his associates at the Rand Corporation, California. This method is recommended as a form of structured group communication process. Because repeated questionnaires are used as the main tool to reduce individual dominance to develop consensus on a matter. This technique aims to avoid the friction that occurs due to the prominence of someone's idea that is better than other people's ideas in a forum to reach a concession (Gossler, Sigala, \& Wakolbinger, 2019).

In the Delphi concept, expert panelists are selected and their identities are kept confidential. This group of expert panelists is selected selectively and in a position to represent experts who understand the problem for which consensus is to be found. These expert panelists were then asked to fill out a questionnaire in writing and collect it. After this first result collection, the panelists' answers will be combined to create new questions in the next round of questionnaires. The process of taking the answers to this questionnaire will be repeated several times until a consensus is reached from the overall answers of the expert panelists (Nugroho, et al., 2020).

\subsection{The Concept of AHP Analysis}

AHP or Analytical Hierarchy Process analysis is an analytical method developed to find the priority order or ranking of the various alternatives contained in problem-solving efforts. This analysis was developed by prof. Thomas Lorie Saaty from Wharston Business School. In a complex situation, decision making is influenced by many factors covering various levels and interests (Nawal Sael, 2019). So it is necessary to determine priorities and test the consistency of the various options that exist. AHP is a general theory of measurement used to find the ratio scale of discrete or continuous paired comparisons. This comparison can be obtained from actual measures as well as a basic scale that reflects the strength of feelings and relative preferences. 


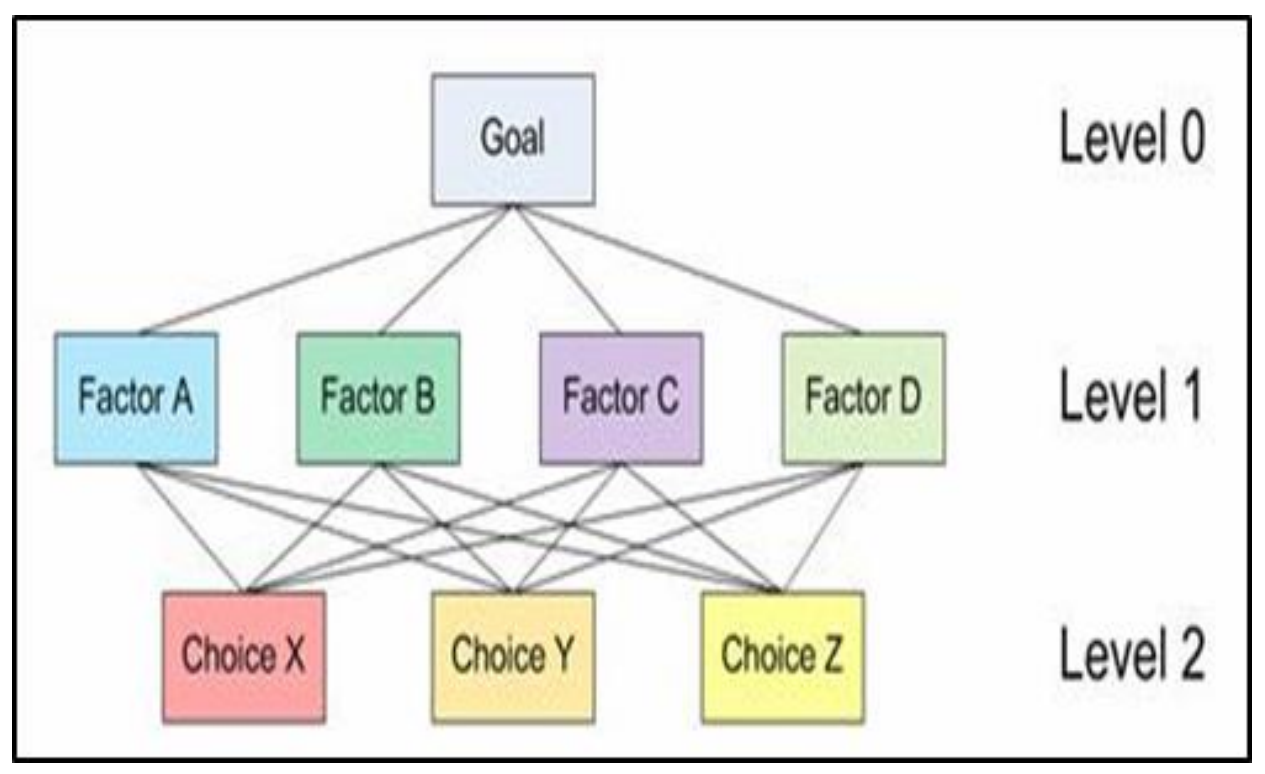

Figure 1 AHP Hierarchical Structure

\subsection{Library}

The existence of a library as a means of support in an institution or school has received a lot of attention so far, this is because it is considered by many parties that the library still needs a lot of attention. This can be seen from the low development of the library itself and the low interest of readers to visit and utilize the library as an ideal place to obtain information needed in education (Nugroho, et al., 2019).

The definition of a library in simple terms is a form of learning resource organization that collects various information in the form of books and non-books that can be used by users (such as teachers, students, and the community) to develop their abilities and skills. By utilizing the library, some data or information can be obtained to solve various problems, sources for determining certain policies, and various things that are very important for learning needs at school. The essence of the library is a learning resource center and a source of information for its users.

The purpose of library activities is to foster readers' interest in reading, introduce information technology, familiarize themselves with access to information, and foster the talents and interests of users. When viewed from its relationship with the teaching and learning process in schools, the school library provides a very valuable contribution to increase student activity and improve the quality of education and teaching (Ilahi, Widiaty, Wahyudin, \& Abdullah, 2019).

Judging from its role, the library is a student partner in learning, providing guidance/education to students in using libraries and information sources, providing the latest information, preparing study rooms, discussions, and research. In essence, the library is a learning resource available from various learning resources in the school environment.

\subsection{Methodology}

To solve the problem of optimizing the library as a learning resource in schools in research, several steps are needed to describe the approach and model of the problem. The steps taken are: 


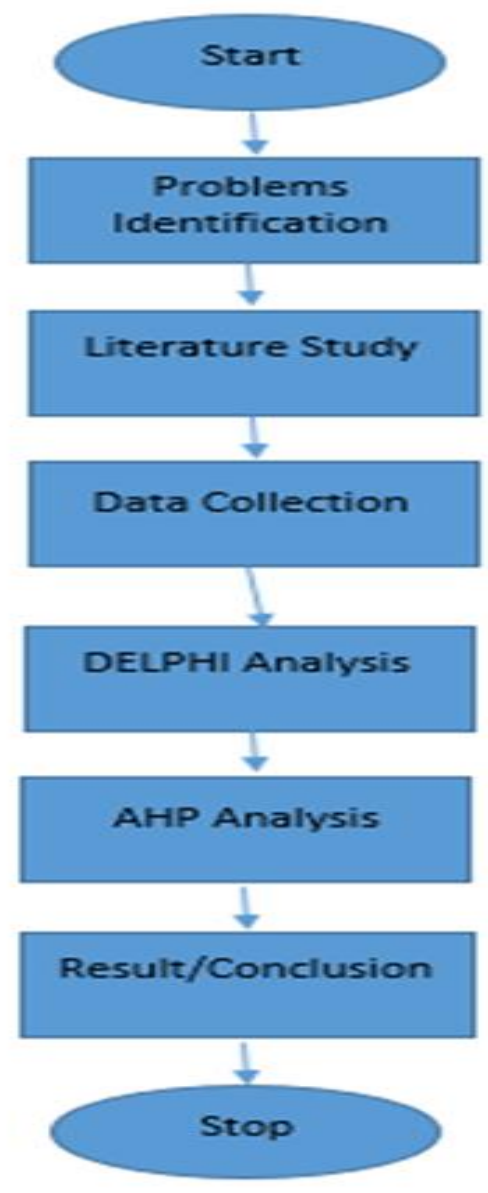

Figure 2 Research Flow Chart

Target: The purpose of this research is to find a strategy that can be implemented to improve the function and role of the school library as a learning resource.

Steps: The steps of this research are: step 1 filter out all the criteria that affect the process that affects the development of libraries as a learning resource with the Delphi method, step 2 performs analysis, step 3 analyzes the system using AHP, step 4 provides suggestions for improvement and conclusions.

\section{Results and discussion}

\subsection{Delphi Analysis to Determine Criteria}

This research was conducted at school X, which was carried out from April to August 2020. With experts or experts who are involved in the development of the school library X. In this study, it is described that the library is a system that has software in the form of services, hardware in the form of buildings, and brain ware in the form of a librarian, so this study only discusses the ideal reconstruction of the three elements.

The Delphi process is carried out by asking questions to experts to get some very influential criteria in developing a library as a learning resource in school X. Some of the existing criteria are then confirmed to other experts in turn until a criterion is found agreed upon by library development experts at school X.

The assessment of the reasons why it is necessary to develop a library at school $\mathrm{X}$ as a learning resource is as mandated by Law No. 43 of 2007 concerning Libraries. In this law, it is said that the library is ideal if the standard size is clear. This means that it is said to be ideal if the library at school X, at least in implementation, management, and implementation, has referred to the predetermined standards or standard rules. 
The problem that arises is that the implementation has not been directed and maximized as expected. It seems that concrete steps are needed so that librarians get back up and clean up to follow the developing model. The point is that with the development of Information and Communication Technology, libraries need support in terms of information service management.

In its current development, library services are no longer limited to borrowing and returning books, but currently, several libraries have improved their service quality by utilizing existing information technology. Digital collection services are very much needed. The advantage of digital collection services is that they can provide flexibility for more users and at the same time to utilize the same information sources.

Audio-visual services are also important to be held in libraries. These services are related to information packaged in the form of cassettes, DVDs, and so on. In this service, the library provides audio-visual equipment so that users can directly access the information contained in the media.

Next is the issue of Learning Common, which is a learning facility provided by the library and is designed in such a unique way by bringing together several learning support facilities. Students can carry out various activities in the learning process in the library, for example, the desired option is group study where they need a closed room, so the library provides the need for that space. If students want a presentation using LCD media, the library must also provide this equipment. Common learning services also have supporting facilities that are usually available, namely computers, wifi access, comfortable seating arrangements with ergonomic seating designs, and the provision of several meeting rooms.

Experts also mentioned multitasking problems in developing libraries as a learning resource in school X. Traditional library jobs such as acquisition, processing, dissemination of information, and management can be done on one computer with a shorter procedure than manual management. Librarians can receive orders to search for information on a topic, conduct searches inside and outside the library, order at a bookstore or download via the internet, process the information obtained, and convey it to the customer without having to change computers let alone traveling outside the library. When searching for information, users can get a source of non-personal information, but also several names of users who have expertise in their fields, then users can click and consult with that person. Also, the written work that is done can be sent to the people he wants, and also users can put their work in the library database so that anyone can provide input.

Next is Makerspace, which is one of the trends in learning libraries, the library has now developed and is changing its role to become a maker space where libraries not only provide information and reading material to improve the reading culture of students, but libraries now give freedom of space to students, especially children, and adolescents, to apply the skills obtained from reading in the library. Makerspace is a place where users can gather to be creative, create things, and learn new things.

The assessment of the reasons for the library development strategy as a learning resource in school X is based on the Stages of Research Using the Delphi Concept. There are several criteria for library development as a learning resource in school X, namely: digital services, audio-visual services, common learning services, multitasking services, and maker space services. From the criteria obtained from the Delphi results, the priority order will be determined using AHP analysis.

\subsection{Determination of Criteria Weight Using AHP (Analytical Hierarchy Process)}

The next stage of this research is after processing the Delphi concept questionnaire data with four stages, which is to determine priority strategies through the method Analytical Hierarchy Process and in this data processing process is carried out using the help of Excel software, with the data processed is questionnaire data which is the perception of respondents/experts. Regarding the criteria of the library development strategy as a learning resource in school X. At this stage, paired comparison weighting is carried out against the criteria for the reasons why a library development strategy is needed as a learning resource in school $X$, namely weighting between criteria with the criteria for common learning services (X1), digital collection services (X2), multitasking service (X3), audiovisual service with weight (X4) and space maker service (X5) (Suharjo, et al., 2019). 


\begin{tabular}{|llllll|}
\hline Criteria & $\mathbf{X 1}$ & $\mathbf{X 2}$ & $\mathbf{X 3}$ & $\mathbf{X 4}$ & $\mathbf{X 5}$ \\
$\mathbf{X 1}$ & 1 & 5 & 3 & 5 & 2 \\
$\mathbf{X 2}$ & 0.2 & 1 & 0.25 & 4 & 0.5 \\
X3 & 0.333333 & 4 & 1 & 5 & 1 \\
X4 & 0.2 & 0.25 & 0.2 & 1 & 0.5 \\
X5 & 0.5 & 2 & 1 & 2 & 1 \\
\hline
\end{tabular}

Figure 3 Results of the criteria matrix normalization

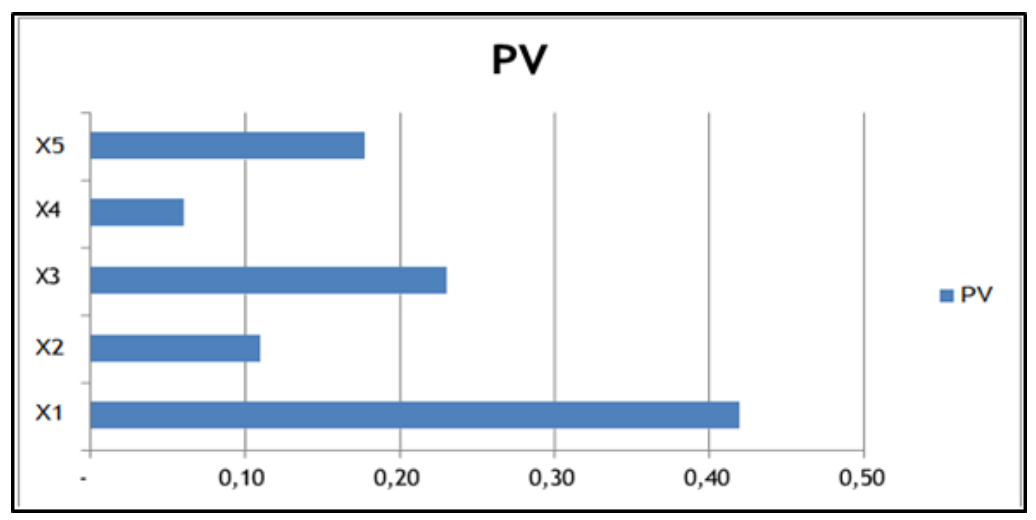

Figure 4 Results of pairwise comparison between criteria

Based on the results of the total weight value in the Figure above, it can be seen that the development strategies that have a big influence in determining library development as a learning resource in school X are: 1) common learning services with the highest weight, 0.42. 2) multitasking service with a weight of 0.23 . 3) maker space with a weight of 0.18. 4) digital collection services with a weight of 0.11. 5) audio-visual services with a weight of 0.06 .

\subsection{Recommended Strategy Formula}

After the results of the various stages of analysis have been carried out, the next step is to formulate a strategy library development as a learning resource in school X, which includes strategies for fulfilling Human Resources, improving the quality of Human Resources, and several strategies for developing libraries as learning resources in school X. The strategy was made so that the development of libraries as learning resources in school X would be able to create ease of access and use of the library. The following are recommendations for the formulation of a library development strategy as a learning resource in school X.

To increase the role and function of the school library X as a learning resource, the first thing that must be done following the opinion of the experts is to provide common learning services. This service is very useful and beneficial for library visitors. The provision of common learning facilities and infrastructure can be done in priority by considering the existing funding conditions. This service allows visitors to carry out various activities in the learning process in the library, for example, the desired option is group study where they need a closed room, so the library provides the need for that space. If students want a presentation using LCD media, the library must also provide this equipment.

To improve multitasking services, the X school library must be able to coordinate with relevant officials in making this happen. The multitasking service allows visitors when searching for information, can get non-personal information sources, but also several usernames who have expertise in their fields, then users can click and consult that person. Besides, the written work that is done can be sent to the people he wants, and also users can put their work in the library database so that anyone can provide input. 
To provide a maker space service, the school library X must innovate while considering the place and cost to be used. Makerspace is a place where users can gather to be creative, create things, and learn new things.

Digital and audio-visual services are the fourth and fifth of the criteria for developing the X school library as a learning resource. These two things are also very necessary to create convenience for library visitors. A good library is a library that can bring in a lot of visitors to learn to find information both individually and in groups. Some of these development strategies can be implemented within the next five years.

\section{Conclusion}

Judging from its role, the library is a student partner in learning, providing guidance/education to students in using libraries and information sources, providing the latest information, preparing study rooms, discussions, and research. In essence, the library is a learning resource available from various learning resources in the school environment.

By looking at the weight value obtained in the AHP analysis, the main priority in the library development strategy as a learning resource in school X is 1) Common learning services with the highest weight, 0.42. 2) Multitasking service with a weight of 0.23. 3) Maker space service with a weight of 0.18.4) Digital collection service with a weight of 0.11 . And 5) Audiovisual services with a weight of 0.06 .

School X library must make efforts to achieve this strategy within five years and can be added with an additional performance measurement model.

\section{Compliance with ethical standards}

\section{Acknowledgments}

The authors greatly acknowledge the support from the Indonesian Naval Technology College STTAL Surabaya Indonesia for providing the necessary resources to carry out this research work. The authors are also grateful to the anonymous reviewers and journal editorial board for their many insightful comments, which have significantly improved this article.

\section{Disclosure of conflict of interest}

The authors declared no potential conflicts of interest with respect to the research, authorship, and/or publication of this article.

\section{References}

[1] Ahmed O, Khanam M. Learning Resources Management Strategies and Academic Achievement Secondary School Students. The International Journal of Indian Psychology. 2014; 108-115.

[2] Alammary, Sheard, Carbone. Three different design approaches. Australasian Journal of Educational Technology. 2014; 40-54.

[3] Bandono ADI, Suharyo OS, Riono. Applied fuzzy and Nasa TLX method to measure of the mental workload. Journal of Theoretical and Applied Information Technology. 2019; 97(2): 476-489.

[4] Bento R, White L. Strategic performance management systems: Impact on business results. Journal of Computer Information Systems. 2014; 25-33.

[5] Busljeta. Effective Use of Teaching and Learning Resources. Czech-Polish Historical and Pedagogical Journal. 2013; 55-69.

[6] Chodhury, Gouldsborough, Gabriel. Use interactive Sessions and E-learning in Teaching Anatomy to First-year Optometry students. Anat Sci-Education. 2010; 39-45.

[7] Chu, Zhang CC. The effectiveness of wikis for project-based learning in different disciplines in higher education. The Internet and Higher Education. 2017; 49-60.

[8] Crook, Fisher, Harrison. Web 2.0 technologies for learning: the current landscape-opportunities, challenge, and tensions. Technology learning. 2008. 
[9] Fariyatul E, Bandono A. The use of value clarification technique-based- picture story media as an alternative media to value education in primary school. Harmonia Journal of art Research and Education. 2017; 68-74.

[10] Gossler T, Sigala IF, Wakolbinger T. Applying the Delphi method to determine best practices for outsourcing logistics in disaster relief. 2019; 438-474.

[11] Guy, Byrne, Dobos. Optional Anatomy and physiology E-learning resources: student access, learning approaches, and academic outcomes. Adv Physiology Education. 2018; 3-9.

[12] Ilahi R, Widiaty, Wahyudin, Abdullah. Digital Library as learning resources. Annual Applied Science and Engineering Conference. 2019; 1-7.

[13] Liu Y. Social Media Tools as a Learning Resource. Journal of Educational Technology Development and Exchange. 2010; 101-114.

[14] Marina F. Barriers to adult learning: Bridging the gap. Australian Journal of adult learning. 2011; 583-590.

[15] Mashudi A, Rahman A, Bandono A, Hasan S. STTAL Development Strategy To Produce Human Resources That Acknowledge Technology Facing The Industrial Revolution Era 4.0. INTERNATIONAL JOURNAL OF ASRO-STTAL. 2019; 27-33.

[16] Monica Sisley A, Ross J, Brailsford I, Bhargava A, Jacobs R, Anstice N. Student acceptance of E-learning methods in the laboratory class in optometry. PLOS ONE. 2018; 1-15.

[17] More B. Student perceptions of various E-learning components. Interdisciplinary Journal of E-learning and learning objects. 2008; 114-135.

[18] Nawal Sael TH. Implementation of the Analytic Hierarchy Process for Student Profile Analysis. International Journal of Emerging Technologies in Learning (iJET). 2019; 78-93.

[19] Nugroho SH, Madhakomala R, Gunawan K. The system dynamic model for policy evaluation of navy personnel on the state-duty aspect. International Journal of Scientific and Technology Research. 2019; 8(12): 228-236.

[20] Nugroho SH, Sukandari B, Suharyo OS, Bandono A. The application of Nasa-Tlx methods to the analysis of Mtf navy personnel allocation. International Journal of Scientific and Technology Research. 2020; 9(3): 6172-6179.

[21] Rastislav R, Silvia L. Strategic Management of Business Performance Based on Innovations and Information Support in Specific Conditions of Slovakia. Journal of Competitiveness. 2015; 3-21.

[22] Sandanayake TC. Promoting open educational resources-based blended learning. International Journal of Educational Technology in Higher education. 2019; 1-16.

[23] Suharjo B, Suharyo OS, Bandono A. Failure mode effect and criticality analysis (FMECA) for determination time interval replacement of critical components in warships radar. Journal of Theoretical and Applied Information Technology. 2019; 97(10): 2861-2870. 